Article

\title{
Patching vs Packaging in Policy Formulation: Assessing Policy Portfolio Design
}

Michael Howlett ${ }^{1,2}$ and Jeremy Rayner ${ }^{3}$

${ }^{1}$ Department of Political Science, Simon Fraser University, Burnaby, BC V5A 1S6, Canada; E-Mail: howlett@sfu.ca

${ }^{2}$ Lee Kuan Yew School of Public Policy, National University of Singapore, Singapore 259772, Singapore

${ }^{3}$ Johnson-Shoyama Graduate School of Public Policy, University of Saskatchewan, Saskatoon, SK S7N 5B8, Canada;

E-Mail: jeremy.rayner@usask.ca

\section{How to Cite this Article}

Howlett, M., \& Rayner, J. (2013). Patching vs Packaging in Policy Formulation: Assessing Policy Portfolio Design. Politics and Governance, 1(2), 170-182.

\section{Acknowledgement}

This Article was published by Librello, Politics and Governance's former publisher.

\section{About the Journal}

Politics and Governance is an innovative new offering to the world of online publishing in the Political Sciences. An internationally peer-reviewed open access journal, Politics and Governance publishes significant, cutting-edge and multidisciplinary research drawn from all areas of Political Science.

www.cogitatiopress.com/politicsandgovernance

\section{Editors-in-Chief}

Professor Andrej J. Zwitter, Faculty of Law, University of Groningen, The Netherlands

Professor Amelia Hadfield, Department of Psychology, Politics and Sociology, Canterbury Christ Church University, UK

\section{Managing Editor}

Mr. António Vieira, Politics and Governance, Cogitatio Press, Portugal 


\title{
Patching vs Packaging in Policy Formulation: Assessing Policy Portfolio Design
}

\author{
Michael Howlett ${ }^{1,2, *}$ and Jeremy Rayner ${ }^{3}$ \\ ${ }^{1}$ Department of Political Science, Simon Fraser University, Burnaby, BC V5A 1S6, Canada; \\ E-Mail: howlett@sfu.ca \\ ${ }^{2}$ Lee Kuan Yew School of Public Policy, National University of Singapore, Singapore 259772, Singapore \\ 3 Johnson-Shoyama Graduate School of Public Policy, University of Saskatchewan, Saskatoon, SK S7N 5B8, \\ Canada; E-Mail: jeremy.rayner@usask.ca \\ * Corresponding author
}

Submitted: 20 June 2013 | In revised form: 26 August 2013 | Accepted: 2 October 2013 |

Published: 14 October 2013

\begin{abstract}
Thinking about policy mixes is at the forefront of current research work in the policy sciences and raises many significant questions with respect to policy tools and instruments, processes of policy formulation, and the evolution of tool choices over time. Not least among these is how to assess the potential for multiple policy tools to achieve policy goals in an efficient and effective way. Previous conceptual work on policy mixes has highlighted evaluative criteria such as "consistency" (the ability of multiple policy tools to reinforce rather than undermine each other in the pursuit of individual policy goals), "coherence" (or the ability of multiple policy goals to co-exist with each other in a logical fashion), and "congruence" (or the ability of multiple goals and instruments to work together in a uni-directional or mutually supportive fashion) as important design principles and measures of optimality in policy mixes. And previous empirical work on the evolution of existing policy mixes has highlighted how these three criteria are often lacking in mixes which have evolved over time as well as those which have otherwise been consciously designed. This article revisits this early design work in order to more clearly assess the reasons why many existing policy mixes are sub-optimal and the consequences this has for thinking about policy formulation processes and the practices of policy design.
\end{abstract}

Keywords: planning; policy design; policy instruments; policy layering; policy mixes; policy portfolios

\section{Introduction: Policy Portfolios and Policy Design}

Policy design is an activity which unfolds in the policy process as policy actors deliberate and interact over the construction of both the means or mechanisms through which policy goals are given effect and the goals of policy themselves. It is "the effort to more or less

(C) 2013 by the authors; licensee Librello, Switzerland. This open access article was published under a Creative Commons Attribution License (http://creativecommons.org/licenses/by/3.0/). 
systematically develop efficient and effective policies through the application of knowledge about policy means gained from experience, and reason, to the development and adoption of courses of action that are likely to succeed in attaining their desired goals or aims" [1-3]. But public policies are comprised of complex arrangements of policy goals and policy means which can be packaged in a more, or a less, systematic fashion. Why this is the case and how thinking about policy design can be advanced and made more systematic is the subject of this article.

Like 'planning', policy design theory has its roots in the 'rational' tradition of policy studies, one aimed at improving policy outcomes through the application of policy-relevant knowledge to the crafting of alternative possible courses of action intended to address specific policy problems [4-12]. But it extends beyond this to the consideration of the practices, frames of understanding, and lesson-drawing abilities of policy formulators or "designers" in adapting design principles to the particular contexts that call for policy responses $[2,13]$.

Assessing policy designs and the extent to which policy-making can be considered to embody an intentional design logic begins with the recognition that in many circumstances, policy decisions will be more highly contingent and 'irrational' than in others [14]. That is, there is no doubt that in many cases policymaking is driven by situational logics and opportunism rather than careful deliberation and assessment [15-19].

This high level of contingency has led some critics and observers to suggest that policies cannot be 'designed' at all, at least in the sense that a house or a piece of furniture can be the product of conscious and systematic design fashioned and put into place by one or more 'designers'. But those who have written about policy design disagree with this assessment. Recognizing the dialectic existing between principle and context they distinguish the formulation process from the actual design of a policy itself [20]. In much the same way as the development of an architectural plan can be distinguished from its engineering or construction manifestations, optimal policy designs in this sense can be thought of in a 'meta' or abstract sense as 'ideal types', that is, as configurations of elements which can reasonably be expected, if adopted with due attention given to specific contextual settings and needs, to have a higher probability of delivering a specific outcome than some other configuration. Whether or not this potential is actually realized in practice is another matter and the subject of separate, although clearly related, investigation and inquiry.

This article explores this meta-orientation to the study of policy designs. Bracketing the actual process of policy formulation which may or may not provide auspicious conditions for a 'design orientation', it first revisits several 'first principles' for policy portfolio design found in the policy design literature and addresses the nature of the evaluative criteria used to distinguish 'good' from 'poor' design. Returning to the ground of actual policy-making, it then moves on to consider issues such as the 'degrees of freedom' or room to manouevre which designers have in developing and implementing their designs and the ideas of 'maximizing complementarity' and 'goodness of fit' with existing governance arrangements with which contemporary design theory is grappling. Finally it develops the notion that two distinct and very different types of design processes have been incorrectly juxtaposed in the literature--"policy patching" and "policy packaging." It suggests the former is more likely to be found in practice than the latter and should be the subject of further research in this area of policy and design studies. The article shows how the early design literature has been refined to incorporate some of the shortcomings identified by subsequent empirical research, and now approaches formulation and design issues fully taking into account restrictions on the abilities of designers to accomplish their designs in practice while offering realistic guidance on how these may be overcome.

\section{Policy Design, Policy Portfolios and Ex-Ante Assessment}

Policy makers typically consider several policy alternatives, some of which, or parts of which, may ultimately be implemented in the attempt to achieve desired outcomes. These are alternative options for how government action can be brought to bear to resolve some identified problem or attain some goal and their articulation and consideration forms the basis of processes of policy formulation.

It is important to note that in this conception policy design is thus both a 'verb'-in the sense of characterizing one manner in which a policy formulation process can unfold in creating a policy configuration sensitive to the constraints of time and place - and also a 'noun'in the sense of being an actual product or artifact that can be compared to others [21].

Policy design as a verb involves some process of coordinating disparate actors working in a given spatiotemporal context towards agreement on the content of designs-as-noun. These processes of policy design or formulation are interesting and complex and subjects of inquiry in their own right but, as noted above, can be separated, at least in the abstract, from the 'designas-noun' itself. Again, to use an architectural metaphor, this is true in much the same way as craftsmanship and skill in construction are significant factors involved in realizing a building vision but can be considered separately from the vision itself; which can be assessed not only against its concrete realization but also against aesthetic and other criteria for assessing 'good' from 'poor' designs [21-24].

But what is it that is 'designed' in policy design? In all but the very simplest contexts, policy alternatives are options for government action comprised of different sets of policy means-that is policy tools and their 
calibrations-bundled together into packages of measures which are expected by their designers to be capable of attaining specific kinds of policy outcomes [25-28]. "Policy designs" in this sense refer to how specific types of policy tools or instruments are bundled or combined in a principled manner into policy 'portfolios' or 'mixes' in an effort to attain policy goals.

Analyzing policy design in the context of such policy portfolios raises a series of questions about how exactly the superiority of the design of one mix over another can be assessed ex-ante. A design perspective in general assumes that not all designs are equal nor is one design just as good as any other, and a subject of much interest to students of policy designs, therefore, is the nature of the evaluative criteria which can be used to identify "better" or more 'intelligent' designs and distinguish them from 'poor' designs, and from 'non-designs'.

Various design principles have been articulated at various points in the history of studies of policy formulation and policy tool choice with this end in mind. And the merits and demerits of some of these efforts are set out below. As shall be discussed, rules or maxims have been proposed both about how many tools and goals there should be in a bundle and about how tools should be combined in order to stand the best chance of attaining these goals [29]. The former is a subject which received some attention as early as the 1950s and resulted in the development of several principles of policy design which emphasized aesthetics of simplicity and elegance. The latter issue received some attention in the 1970s and 1980s as scholars emphasized a need to avoid unreflexive preferences for the use of highly coercive tools on the part of governments and instead urged sequenced designs which began slowly with the use of the least 'interventionist' tools possible before 'moving up' to the use of more coercive designs only if and so far as less coercive ones proved unable to accomplish stated goals.

While these areas were the subjects of most early thinking about policy mixes, more recent design thinking has begun to address a second series of questions related to the larger issues of how and to what extent tools must not only be related logically or evidentially to each other but must also must match their policy environments in order to be both practically feasible as well as theoretically elegant. That is, designs have come to be seen as involving the need to go beyond just a logical or theoretical match of policy elements to goals but also must involve a match between the social construction and ecological adaptation of policy [30], or between 'principle' and 'context' [31]. This is in much the same way as architectural designs can either ignore or reflect and incorporate their geo-physical settings with most designers advocating the latter course as generating more pleasing and effective results.

This more recent thinking about the nature of policy mixes and their design has raised several new issues for policy design thinking which add an additional layer of complexity to earlier analyses and principles. Older concepts such as consistency', 'coherence', and 'congruence' which set out the goals towards which complex designs should aspire have now been joined by other considerations such as those concerning what level or 'degrees of freedom' designers have in moving towards new designs or building on old ones. Such considerations often promote 'policy experiments' or trial runs and pilot projects which may or may not be scaled up into full-blown programmes depending on their outcomes as a means to determine policy fit to practice $[32,33]$ and have led to suggestions for more resilient or adaptable designs which retain adequate 'flexibility' or adaptive elements to allow them to be adjusted to changing circumstances once in place $[33,34]$.

These studies take very seriously the need to 'match' design to both spatial and temporal contexts that were lacking in earlier studies. To this end they have developed a new set of maxims to replace those earlier ones often found faulty or limited when applied to policy-making practice. These include injunctions such as those urging flexibility cited above as well as those urging policy formulators to "maximize complementary effects" in their choice of tools and goals. They also include precepts related to the need to better match policy designs and policy designing or formulation activities, such as considerations of how to assess the goodness of fit between policy elements and their environments in the effort to match policy designs with governance contexts. These existing and new design principles and maxims are discussed in more detail below.

\section{Older Design Maxims and Their Problems}

Contemporary thinking about policy formulation and policy designing is firmly rooted in an older literature on policy design which over the course of the 1950s to 1990s developed several maxims or heuristics expected to be used to head off common errors or sources of failure in policy-making. These included the promotion of parsimonious tool use in policy mixes, the injunction to begin with less coercive tools and only move towards increased coercion of policy targets as necessary, and the adoption of the above-mentioned notions of coherence, consistency and congruence as criteria for assessing the level of optimality of the arrangement of elements in a policy mix. Although a good start, as noted below only limited empirical evidence supported the accuracy and utility of these principles, which tended to underestimate the difficulties involved in formulating and implementing complex policy mixes. As these faults were recognized, new efforts to think about more complex policy designs have led to a new generation of design thinking in this area and the articulation of a new set of principles and practices expected to result in superior designs; that is, ones more likely to reach their targets and achieve their goals [35-38]. 


\subsection{Parsimonious Tool Use}

The first and oldest maxim in the policy design literature is the injunction to observe parsimony in tool selection. An oft-cited rule in this area, for example, was first put forward by Jan Tinbergen in 1952 [29], to the effect that the "optimal ratio of the number of tools to targets" in a policy should be $1: 1$ [39]. That is, that the number of policy tools in any mix should roughly match the number of goals or objectives set for a policy.

This may appear to be a reasonable rule-of-thumb, for which Tinbergen provided some logical justification in his discussion of the information and administrative costs associated with the employment of redundant tools in the area of economic policy-making. In his work, for example, Tinbergen analyzed what he termed the 'normal' case in which one goal was matched with one target in a simple situation in which one instrument could fully address its task and accomplish the goal set out for it. Most observers, however, including Tinbergen, were well aware that in practice combinations of tools are typically used to address single and especially multiple policy goals, not a single instrument addressing a single goal. In such circumstances, as Tinbergen [29] noted "it goes without saying that complicated systems of economic policy (for example) will almost invariably be a mixture of instruments" (p. 71). As a result he himself argued "a priori there is no guarantee that the number of targets (goals) always equals the number of instruments" (p. 37).

Such admonitions and caveats about design complexity, unfortunately, were usually neglected in studies ostensibly based on Tinbergen's work, with many erstwhile designers attempting to force complex situations into the more simple mould required for Tinbergen's rule to apply [39]. More contemporary thinking about policy design, however, begins not with single instrument choices at specific moments in time de novo, but rather with considerations of designing mixes of tools which specifically take into account the spatio-temporal complexities missing in earlier design studies $[25,26]$. Thus they move well 'beyond the Tinbergen Rule' in the effort to inform modern design contexts and practice in a meaningful way.

\subsection{Moving Up the Scale of Coercion in Sequential Instrument Choices}

A second principle of policy design found in the older literature on the subject was not only the injunction to be parsimonious in the number of instruments chosen at a specific point in time in order to attain a goal, but also to be sparing in their use dynamically or sequentially over time. In the mid-1970s and early 1980s, for example, Bruce Doern, Richard Phidd, Seymour Wilson and others published a series of articles and monographs that placed policy instruments on a single continuum based on the 'degree of government coercion' each instrument choice entailed [30-44]. They argued that choices of tools, or policy designs, should only 'move up the spectrum' of coercion as needed so that the 'proper' sequencing of tool types in a policy mix would be from minimum levels of coercion towards maximum ones [45]. Assuming that all instruments were more or less technically "substitutable" or could perform any task-although not necessarily as easily or at the same cost-it was argued that in a liberal democratic society, governments, often for both ideological and pragmatic reasons, would prefer to, and should, use the least coercive instruments available and would only employ more coercive ones as far as was necessary in order to overcome societal resistance to attaining their goals. As Doern and Wilson ([45], p. 339) put it:

"(...) politicians have a strong tendency to respond to policy issues, (any issue) by moving successively from the least coercive governing instrument to the most coercive. Thus they tend to respond first in the least coercive fashion by creating a study, or by creating a new or re-organized unit of government, or merely by uttering a broad statement of intent. The next least coercive governing instrument would be to use a distributive spending approach in which the resources could be handed out to constituencies in such a way that the least attention is given as to which taxpayers' pockets the resources are being drawn from. At the more coercive end of the continuum of governing instruments would be a larger redistributive programme, in which resources would be more visibly extracted from the more advantaged classes and redistributed to the less advantaged classes. Also at the more coercive end of the governing continuum would be direct regulation in which the sanctions or threat of sanctions would have to be directly applied."

This rationale for instrument choice clearly took policy context into account in making design decisions and moved design discussions such as Tinbergen's forward in that respect. That is, Doern and his colleagues work was based on an appreciation of the ideological preferences of liberal-democratic societies for limited state activity and on the difficulties this posed for governments in the exercise of their preferences due to the relative "strength" or ability of societal actors to resist government efforts to shape their behaviour.

This formulation has many advantages as a design principle. It is not uni-dimensional, although it might appear so on first reading, because it does take into account several political and contextual variables and assumes instrument choices are multi-level, with finer calibrations of instruments emerging after initial broad selections of tools have been made [46]. Preferring "self-regulation", for example, governments might first attempt to influence overall target group performance 
through exhortation and education efforts and then add instruments to this mix only as required in order to compel recalcitrant societal actors to abide by their wishes, eventually culminating, if necessary, in regulation or the public provision of goods and services.

This maxim was based on both observations of the actual design practices followed by many governments which were used to develop and inform a set of principles informing 'proper' or appropriate overall tool preferences. However, as Woodside [47] argued, it was lacking in several ways. As he put it:

\begin{abstract}
"Experience suggest that governments do not always seek to avoid coercive solutions, but indeed, may at times seem to revel in taking a hard line from the start. While there are undoubtedly many reasons for these heavy handed responses, surely some of the most important ones include the constituency or group at which the policy is aimed, the circumstances in which the problem has appeared, and the nature of the problem involved" ([47], p. 786).
\end{abstract}

Hence although suggestive, this second design principle also needed nuance and revision. These and other similar concerns led to further efforts in the 1990s to deal with the complexities of policy design, especially in the context of mixes or bundles of tools.

\subsection{Coherence, Consistency and Congruence as Measures of Design Integration and Criteria of Superior Design}

These early efforts from the 1970 s and 1980 s to articulate fundamental policy design principles were overtaken in the 1990s by work which focused on the need to articulate a set of general principles which would more clearly inform the selection of the various parts of a mix or portfolio, bracketing for a moment the issue of formulation processes and policy outcomes. Here it was noted that policies are composed of several elements: distinguishing between abstract or theoretical/ conceptual goals, specific programme content or objectives, and operational settings or calibrations [48-50]-for example, as set out in Table 1 . The central criteria which the design literature developed for dealing with how these multiple parts of a policy should be related was the notion of 'integration' or the idea that goals and means within mixes should not work at cross-purposes but mutually reinforce each other [51-53].

That is, moving beyond Tinbergen's rule, it was argued that some correspondence across elements was required if policy goals were to be successfully matched with policy means $[49,51]$. And it was argued that a relatively small number of criteria could be identified to help assess the extent to which existing or future mix elements were integrated [54].

Previous work on policy design had identified one such evaluative criteria in the notion of "consistency" or the ability of multiple policy tools to reinforce rather than undermine each other in the pursuit of policy goals. A second such criteria related to goals rather than means. Here the idea of "coherence" or the ability of multiple policy goals to co-exist with each other and with instrument norms in a logical fashion was developed. Finally the idea of "congruence" or the ability of goals and instruments to work together in a uni-directional or mutually supportive fashion rounded out these three integrative dimensions proposed for a superior policy design [55].

Table 1. Components of a policy mix.

\begin{tabular}{|c|c|c|c|c|}
\hline & \multicolumn{4}{|c|}{ Policy Content } \\
\hline & & High Level Abstraction & $\begin{array}{l}\text { Programme Level } \\
\text { Operationalization }\end{array}$ & $\begin{array}{c}\text { Specific On-the-Ground } \\
\text { Measures }\end{array}$ \\
\hline \multirow[t]{2}{*}{$\begin{array}{l}\text { Policy } \\
\text { Focus }\end{array}$} & $\begin{array}{l}\text { Policy } \\
\text { Ends or } \\
\text { Aims }\end{array}$ & $\begin{array}{l}\text { Goals } \\
\text { What General Types of } \\
\text { Ideas Govern Policy } \\
\text { Development? (e.g. } \\
\text { environmental } \\
\text { protection, economic } \\
\text { development) }\end{array}$ & $\begin{array}{l}\text { Objectives } \\
\text { What Does Policy } \\
\text { Formally Aim to Address? } \\
\text { (e.g. saving wilderness or } \\
\text { species habitat, } \\
\text { increasing harvesting } \\
\text { levels to create } \\
\text { processing jobs) }\end{array}$ & $\begin{array}{l}\text { Settings } \\
\text { What are the Specific On-the- } \\
\text { ground Requirements of } \\
\text { Policy (e.g. considerations } \\
\text { about the optimal size of } \\
\text { designated stream-bed } \\
\text { riparian zones, or sustainable } \\
\text { levels of harvesting) }\end{array}$ \\
\hline & $\begin{array}{l}\text { Policy } \\
\text { Means or } \\
\text { Tools }\end{array}$ & $\begin{array}{l}\text { Instrument Logic } \\
\text { What General Norms } \\
\text { Guide Implementation } \\
\text { Preferences? (e.g. } \\
\text { preferences for the } \\
\text { use of coercive } \\
\text { instruments, or moral } \\
\text { suasion) }\end{array}$ & $\begin{array}{l}\text { Mechanisms } \\
\text { What Specific Types of } \\
\text { Instruments are Utilized? } \\
\text { (e.g. the use of different } \\
\text { tools such as tax } \\
\text { incentives, or public } \\
\text { enterprises) }\end{array}$ & $\begin{array}{l}\text { Calibrations } \\
\text { What are the Specific Ways in } \\
\text { Which the Instrument is used? } \\
\text { (e.g. designations of higher } \\
\text { levels of subsidies, the use of } \\
\text { mandatory vs. voluntary } \\
\text { regulatory guidelines or } \\
\text { standards) }\end{array}$ \\
\hline
\end{tabular}

Source: modified from [50]. 
The development of such criteria was a significant advance over the earlier works mentioned above and moved policy design thinking well beyond other frameworks developed around the same time which purported only to develop a series of 'hints' for policy-makers to follow in promoting better designs $[56,57]$.

However, while clear enough in theory, these works raised to the forefront the need to, like Doern and his colleagues had done, re-integrate thinking about policy 'design-as-noun' with 'design-as-verb' or policy formulation $[58,59]$. This was because empirical work on the evolution of long-term policies or 'institutions' highlighted how these three criteria were often only weakly represented in existing mixes, especially those which have evolved over a long period of time $[60,61]$. That is, empirical research into policy designs in practice revealed considerable gaps between the coherency, consistency and congruence of actual policy mixes compared to their theoretical specification and highlighted the need to consider the temporal evolution of tool portfolios, much as Doern and his colleagues had done several decades earlier [62].

\section{Modern Principles of Policy Design: Complementary Effects, Goodness of Fit and Degrees of Freedom}

Recent design thinking has built on this basis in earlier studies and has underlined the importance of considering both the full range of policy instruments when designing a mix-rather than assuming that a choice must be made between only a few alternatives such as regulation versus market tools [63]-as well as ensuring that a proposed mix is compatible with existing governance arrangements [64]. Towards this end, several new principles have emerged in the current design literature. These include "maximizing complementary effects" and "goodness of it", or attempting to ensure a good fit between policies elements and between those elements and their governance context.

\subsection{Maximizing Complementary Effects}

A major issue and insight driving contemporary design studies concerns the fact that not all of the tools potentially involved and invoked in a policy mix are inherently complementary [65-67] in the sense that they may evoke contradictory responses from policy targets [68-73] and thus fail to achieve their goals. At the same time, of course, some combinations may also be more virtuous in the sense of providing a mutually reinforcing or supplementing arrangement [74]. Similarly, some other arrangements may be unnecessarily duplicative while in others some level of redundancy may be advantageous in ensuring that a stated goal will be achieved $[75,76]$.

Grabosky [66] and others worked on these issues throughout the mid-to-late 1990s, noting that some tools necessarily counteract each other-for example, using command and control regulation while also attempting voluntary compliance-and thus those combinations should be avoided in 'smart' policy designs. Hou and Brewer [74] similarly worked on the other side of this design coin, noting that other tools complemented or supplemented each other-for example, using command and control regulation to prevent certain behaviour deemed undesirable and financial incentives to promote more desired activities at the same time-and thus those combinations should be encouraged.

A key principle of current policy design thinking, therefore, is to try to maximize supplementary effects while minimizing counterproductive ones. "Smarter" designs are thus said to involve the conscious creation of policy packages which take these precepts into account in their formulation or packaging $[64,65,77,78]$.

\subsection{Goodness of Fit: The Need for Designs to Match Governance Mode and Policy}

Contemporary design thinking also highlights the need for designs to respond not only to such general theoretical design principles but also to the particular, contextdependent features of the policy sector involved [26]. In this sense, "goodness of fit" between the policy mix and its governance context is a concern and can be seen to occur at several different levels.

That is, at one level design choices emerge from and must generally be congruent with the governance modes or styles practiced in particular jurisdictions and sectors. This is because different orientations towards state activity involved in policy mixes require specific capabilities on the part of state and societal actors which may only be forthcoming if the mix matches the governance context. Policy designs, it is argued, thus must take into account the actual resources available to a governmental or non-governmental actor in carrying out their appointed roles in policy implementation [79]. Thus, for example, planning and 'steering' involve direct co-ordination of key actors by governments, requiring a high level of government policy capacity to identify and utilize specific policy tools capable of successful moving policy targets in a required direction $[80,81]$.

Work on 'policy styles' [82-84] in the 1980s and 1990s identified a number of common patterns and motifs in governance arrangements in specific sectors and jurisdictions which contemporary design theory argues designs in different jurisdictions should reflect $[26,79,85]$. While many permutations and combinations of possible governance arrangements exist, recent policy and administrative studies have focused on four basic or 'ideal' types found in many jurisdictions and sectors in liberal democratic states. These are the legal, corporate, market and network governance forms (see Table 2). Government actions through legal and network governance, for example, can change many aspects of policy behaviour but do so indirectly through 
the alteration of the relationships existing between different kinds of social actors $[86,87]$. This is unlike corporate and market governance which involves more overt state direction. Each mode has a different focus, form of control, aim and preferred service delivery mechanism and procedural policy orientation which policy designs should incorporate and approximate if they are to be feasible.

This relationship between governance style or context and the policy instruments and goals contained in a policy mix is a significant one for studies of policy design. Since the exact processes by which policy decisions are taken vary greatly by jurisdiction and sector and reflect differences between and within different forms of government-from military regimes to liberal democracies-as well as the particular configuration of issues, actors and problems found in particular areas or sectors of activity-such as health, education, energy and transportation, social policy and many others $[88,89]$ - the existence of a relatively small number of overarching governance modes allows for the matching of design and context in an easily understandable and applicable fashion.

Table 2. Modes of governance.

\begin{tabular}{|c|c|c|c|c|c|}
\hline $\begin{array}{l}\text { Mode of } \\
\text { Governance }\end{array}$ & $\begin{array}{l}\text { Central Focus of } \\
\text { Governance } \\
\text { Activity }\end{array}$ & $\begin{array}{l}\text { Form of State } \\
\text { Control of } \\
\text { Governance } \\
\text { Relationships }\end{array}$ & $\begin{array}{l}\text { Overall } \\
\text { Governance } \\
\text { Aim }\end{array}$ & $\begin{array}{l}\text { Prime Service } \\
\text { Delivery } \\
\text { Mechanism }\end{array}$ & $\begin{array}{l}\text { Key Procedural } \\
\text { Tool for Policy } \\
\text { Implementation }\end{array}$ \\
\hline $\begin{array}{l}\text { Legal } \\
\text { Governance }\end{array}$ & $\begin{array}{l}\text { Legality- } \\
\text { Promotion of law } \\
\text { and order in social } \\
\text { relationships }\end{array}$ & $\begin{array}{l}\text { Legislation, Law } \\
\text { and Rules }\end{array}$ & $\begin{array}{l}\text { Legitimacy- } \\
\text { Voluntary } \\
\text { Compliance }\end{array}$ & $\begin{array}{l}\text { Rights-Property, } \\
\text { Civil, Human }\end{array}$ & $\begin{array}{l}\text { Courts and } \\
\text { Litigation }\end{array}$ \\
\hline $\begin{array}{l}\text { Corporate } \\
\text { Governance }\end{array}$ & $\begin{array}{l}\text { Management-of } \\
\text { Major Organized } \\
\text { Social Actors }\end{array}$ & Plans & $\begin{array}{l}\text { Controlled and } \\
\text { Balanced Rates of } \\
\text { Socio-economic } \\
\text { Development } \\
\end{array}$ & $\begin{array}{l}\text { Targets- } \\
\text { Operational } \\
\text { Objectives }\end{array}$ & $\begin{array}{l}\text { Specialized and } \\
\text { Privileged } \\
\text { Advisory } \\
\text { Committees }\end{array}$ \\
\hline $\begin{array}{l}\text { Market } \\
\text { Governance }\end{array}$ & $\begin{array}{l}\text { Competition- } \\
\text { Promotion of Small } \\
\text { and Medium sized } \\
\text { Enterprises }\end{array}$ & $\begin{array}{l}\text { Contracts and } \\
\text { I Regulations }\end{array}$ & $\begin{array}{l}\text { Resource/Cost } \\
\text { Efficiency and } \\
\text { Control }\end{array}$ & $\begin{array}{l}\text { Prices- } \\
\text { Controlling for } \\
\text { Externalities, } \\
\text { Supply and } \\
\text { Demand }\end{array}$ & $\begin{array}{l}\text { Regulatory } \\
\text { Boards, Tribunals } \\
\text { and Commissions }\end{array}$ \\
\hline $\begin{array}{l}\text { Network } \\
\text { Governance }\end{array}$ & $\begin{array}{l}\text { Relationships- } \\
\text { Promotion of Inter- } \\
\text { actor } \\
\text { organizational } \\
\text { Activity }\end{array}$ & Collaboration & $\begin{array}{l}\text { Co-Optation of } \\
\text { Dissent and Self- } \\
\text { Organization of } \\
\text { Social Actors }\end{array}$ & $\begin{array}{l}\text { Networks of } \\
\text { Governmental, } \\
\text { and Non- } \\
\text { Governmental } \\
\text { Organizations }\end{array}$ & $\begin{array}{l}\text { Subsides and } \\
\text { Expenditures on } \\
\text { Network } \\
\text { Brokerage } \\
\text { Activities }\end{array}$ \\
\hline
\end{tabular}

Source: modified from $[90,91]$.

\subsection{Degrees of Freedom}

A third key concept which has emerged in contemporary design thinking around this same issue is that of 'degrees of freedom' or the consideration of the relative ease or difficulty with which policy-makers can alter the status quo. That is, if any combination of tools was possible in any circumstance then decision-makers could be thought of as having unlimited 'degrees of freedom' in their design choices. Empirical studies of large scale institutional changes, however, have noted this kind of freedom in combining design elements is quite rare. For example, this can occur in situations of what Thelen [92] terms 'replacement' or 'exhaustion' when older tool elements have been swept aside or abandoned and a new mix is designed or adopted de novo. As Thelen noted, however, most existing mixes or portfolios have rather emerged from a gradual historical process in which a policy mix has slowly built up over time through processes of incremental change or successive reformulation. As Christensen et al. [93] have argued, a key design issue is thus the leeway policy designers have in developing new designs given the pre-existence of historical arrangements of policy elements. This has added a siginificant temporal dimension to policy design studies which early generations of thinking either ignored or downplayed.

That is, in addition to the requirements of "goodness of fit" with prevailing governance modes there are also constraints imposed by existing trajectories of policy development. As Christensen et al. [93] note, "these factors place constraints on and create opportunities for purposeful choice, deliberate instrumental actions and intentional efforts taken by political and administrative leaders to launch administrative reforms through administrative design" (p. 158).

How much room for manouevre designers have to be creative [94] or, to put it another way, to what degree they are 'context bound' in thus time and space [26] is a subject of much current interest in contemporary 
design studies. From the historical neo-institutionalist literature cited above it is well understood that complex policy mixes, like institutions, can emerge through several distinct processes or historical trajectories [92, 95-97]. These trajectories-'layering', 'drift', and 'conversion'-differ from 'replacement' and 'exhaustion' in terms of the challenges that they raise for each generation of designers attempting to integrate policy elements in effective, complementary, or 'smart' mixes with coherent goals, consistent means, and congruency of goals and instruments. Layering is a process whereby new elements are simply added to an existing regime without abandoning previous ones, typically leading to both incoherence amongst the goals and inconsistency with respect to the instruments and settings used. Drift occurs when the elements of a policy mix are deliberately maintained while the policy environment changes. The impact of the policy mix is thus likely to change and this is the result that the designer wants to achieve [98]. Conversion involves holding most of the elements of the policy mix constant while redeploying the mix to serve new goals [99]. While consistency may remain largely intact, conversion poses significant risks of incongruence between the old instrument elements and the new goals that have been introduced.

Replacement is thus not the only, or even necessarily the only desirable, historical context for policy design; it simply imposes the smallest number of constraints on successful design. Except in the case of completely new policy areas or old ones facing the kind of total overhaul envisaged in periods of policy punctuations, however, policy designers, are typically faced with a situation in which an already existing policy mix is already in place and cannot be easily discarded $[100,101]$.

These existing arrangements have commonly emerged or evolved over relatively long periods of time through rounds of previous decisions, and even if they had a clear logic and plan at the outset they may no longer do so [102]. Designers' freedom is thus hemmed in on two sides. First, existing mixes often have accumulated varying degrees of political support from those who benefit from them, ruling out complete replacement [103-105]. In such cases where key instruments in the mix are defended by powerful "instrument constituencies", layering can be an appropriate response since these interests may have no objection to the addition of new instruments provided only that "their" instrument is not touched. Conversion, on the other hand, may be indicated where these instrument constituencies can be persuaded that their favoured instruments may actually be strengthened by the addition of new goals that bring in new political support for the existing mix. Drift can also be the favourite strategy of political interests who are not strong enough to destroy a policy mix whose goals they dislike but, by blocking necessary change, may succeed in reducing or even transforming its impact to something more palatable to them [106].

\section{Policy Packaging and Policy Patching as Design Methods}

This last point raises another area of interest in current design studies, that of the basic mode or style of policy-making best suited to realizing policy designs. An important insight in this regard is that designers can recognize and manipulate the relationships involved in processes such as layering, drift and conversion, just as they can those related to replacement and exhaustion [107].

Hacker, for example, has argued that layering, in many ways the simplest way of changing a policy mix, is a process that can ultimately induce conversion. This is because, as new instruments and goals are added into the mix without abandoning the previous ones, new possibilities for relating goals to instruments open up [108]. Drift, on the other hand, may be deliberately used to engineer a crisis in which replacement becomes a real possibility as the impact of a policy mix diverges ever more obviously from that intended by its original designers, shedding political support along the way. Layering may have a similar outcome while employing the opposite political mechanism when a new instrument, originally a minor part of the policy mix, gradually assumes prominence, perhaps as the result of setting or calibration changes, and attracts defectors from other instrument constituencies [109]. In such situations designers can attempt to patch or restructure existing policy elements rather than propose alternatives de novo in a new package of measures $[59,110]$.

Although there is a strong tradition in the design literature to restrict discussions of design to situations characterized by processes of replacement and exhaustion there is ample existing evidence showing that many existing policy regimes or mixes have instead developed through processes of policy layering, or repeated bouts of policy conversion or policy drift, in which new tools and objectives have often been piled on top of older ones, creating a palimpsest-like mixture of inconsistent and incoherent policy elements [111]. And sweeping it all away and starting again with custom made policy designs capable of meeting contemporary policy challenges may seem to be the obvious solution. Policy packaging of this kind, which deliberately seeks to exploit synergistic relationships between multiple policy instruments, was definitely the explicit or implied preference in most earlier efforts to promote enhanced policy integration and coherence in designs across different policy domains [51-53].

However, recognizing that layering, conversion and drift can also be 'intentionally' designed-much in the same way as software designers issue 'patches' for their operating systems and programmes in order to correct flaws or allow them to adapt to changing circumstances-is a critical insight into design processes with which contemporary design studies is beginning to grapple. Distinguishing between policy packaging and 
policy patching as two methods of attaining the same goal-the heightened coherence, consistency and congruence of complementary policy elements coupled with a better fit between tools and their context-is a needed step towards moving beyond older principles of parsimony and the inexorable use of less coercive tools towards enhancing the ability of policy formulators to deal with policy problems which demand complex governmental responses [112].

\section{Conclusion: Policy Design and the Feasibility of Policy Alternatives}

The purpose and expectations of policy design efforts have always been clear $[113,114]$. Design is an activity conducted by a number of policy actors in the hope of improving policy-making and policy outcomes through the accurate anticipation of the consequences of government actions and the articulation of specific courses of action to be followed. This is to be accomplished by improving assessments of both the theoretical effectiveness as well as the feasibility of policy alternatives [115-118].

Each "policy" however is a complex 'regime' or arrangement of ends and means-related goals, objectives, instruments and calibrations which exist in a specific governance setting and which change over time. Central concerns in the design of policies are thus related to answering questions about how these mixes are constructed, which methods yield superior results and what is the likely result of their (re)design. Understanding these aspects of policy formulation and design and synthesizing knowledge about them into a small number of precepts which policy formulators can follow in their work has always been at the forefront of policy design work.

\section{References and Notes}

1. Bobrow D, Dryzek JS. Policy Analysis by Design. Pittsburgh, PA, USA: University of Pittsburgh Press; 1987.

2. Bobrow D. Policy Design: Ubiquitous, Necessary and Difficult. In: Peter BG, Pierre J, editors. Handbook of Public Policy. London, UK: Sage; 2006. pp. 75-96.

3. Dorst K. The Core of 'Design Thinking' and Its Application. Design Studies. 2011;32(6):521-532.

4. Policy design as a verb shares a large number of features in common with 'planning' but without the strategic or directive nature often associated with the latter. Policy design is much less technocratic in nature than these other efforts at 'scientific' government and administration. However, it too is oriented towards avoiding many of the inefficiencies and inadequacies apparent in other, less knowledge-informed ways of formulating policy, such as pure political bargaining, ad hocism, or trial-and-error. In general, though, it is more flexible than planning in developing general sets
However these considerations must take into account the fact that 'policies' are typically 'bundles' or 'portfolios' of policy tools arranged in policy mixes and that such bundles are typically the outcome of distinctive processes of policy change, in which elements are added and subtracted from the mix over time. Early work on policy design did not always take this to heart and clarifying the principles enunciated and articulated by early policy design proponents and applying them to policy mixes, and distinguishing between intentional and unintentional process of policy change in the development of such bundles has been a central feature of contemporary policy design study and efforts to move policy design processes and understanding forward.

While policy designs can and should be considered in the abstract, understanding how policy change processes create and modify mixes is critical to evaluating the chance of success for any particular policy mix to attain its goals once put into practice. Adding the notion of policy 'patching' to considerations of intelligent design, for example, better connects design considerations to practice than do many earlier discussion firmly centered in the 'planning' orientation. These often rely upon ideas about the ease or need for wholesale policy replacement which do not exist in practice.

Contemporary design discussions centered on the articulation of design principles such as "goodness of fit" in policy formulation, governance and steering, and the 'degrees of freedom' which formulators or designers have in carrying out their work both over space and over time help to complement and advance earlier notions such as parsimony and the gradual ratcheting of coercion, and the need for coherence, consistency and congruence in designs which were a major feature of earlier eras of thinking about design issues.

of alternatives rather than detailed directive 'plans'.

5. Tinbergen J. The Design of Development. Baltimore, MD, USA: The Johns Hopkins University Press; 1958.

6. Tinbergen J. Economic Policy: Principles and Design. Chicago, IL, USA: Rand McNally; 1967.

7. Forester J. Planning in the Face of Power. Berkeley, CA, USA: University of California Press; 1989.

8. Schön DA. Designing: Rules, Types and Words. Design Studies. 1988;9(3):181-190.

9. Schön DA. Designing as Reflective Conversation with the Materials of a Design Situation. KnowledgeBased Systems. 1992;5(1):3-14.

10. May PJ. Reconsidering Policy Design: Policies and Publics. Journal of Public Policy. 1991;11(2):187-206.

11. Voß J-P, Smith A, Grin J. Designing Long-term Policy: Rethinking Transition Management. Policy Sciences. 2009;42(4):275-302.

12. Fischer F, Forester J. Confronting Values in Policy Analysis: The Politics of Criteria. Beverly Hills, CA, USA: Sage; 1987. 
13. Schneider $A$, Ingram $H$. Systematically Pinching Ideas: A Comparative Approach to Policy Design. Journal of Public Policy. 1988;8(1):61-80.

14. Cahill AG, Overman ES. The Evolution of Rationality in Policy Analysis. In: Nagel SS, editor. Policy Theory and Policy Evaluation: Concepts, Knowledge, Causes, and Norms. New York, NY, USA: Greenwood Press; 1990. pp. 11-27.

15. Kingdon JW. Agendas, Alternatives, and Public Policies. Boston, MA; USA: Little Brown and Company; 1984.

16. Cohen MD, March JG, and Olsen JP. A Garbage Can Model of Organizational Choice. Administrative Science Quarterly. 1972;17(1):1-25.

17. Dryzek J. Don't Toss Coins in Garbage Cans: A Prologue to Policy Design. Journal of Public Policy. 1983; 3(4):345-367.

18. Eijlander P. Possibilities and Constraints in the Use of Self-regulation and Co-Regulation in Legislative Policy: Experiences in the Netherlands-Lessons to Be Learned for the EU. Electronic Journal of Comparative Law. 2005;9(1):1-8.

19. Franchino F, Hoyland B. Legislative Involvement in Parliamentary Systems: Opportunities, Conflict and Institutional Constraints. American Political Science Review. 2009;103(4):607-621.

20. Linder SH, Peters BG. The Analysis of Design or the Design of Analysis? Policy Studies Review. 1988; 7(4):738-750.

21. May PJ. Policy Design and Implementation. In: Guy PB, Pierre J, editors. Handbook of Public Administration. Beverly Hills, CA, USA: Sage; 2003. pp. 223233.

22. Gero JS, Smith GJ. Context, Situations, and Design Agents. Knowledge-Based Systems. 2009;22 (8):600-609.

23. McLaughlin S, Gero JS. Requirements of a Reasoning System That Supports Creative and Innovative Design Activity. Knowledge-Based Systems. 1989; 2(1):62-71.

24. Doremus H. A Policy Portfolio Approach to Biodiversity Protection on Private Lands. Environmental Science \& Policy. 2003;6(3):217-232.

25. Howlett M. What Is a Policy Instrument? Policy Tools, Policy Mixes and Policy Implementation Styles. In: Eliadis P, Hill MM, Howlett M, editors. Designing Government: From Instruments to Governance. Montreal, Canada: McGill-Queen's University Press; 2005. pp. 31-50.

26. Howlett M. Designing Public Policies: Principles and Instruments. New York, NY, USA: Routledge; 2011.

27. The need to bundle or mix policy tools together in complex arrangements raises many significant questions for policy design, especially with respect to the nature of decisions about the choice of policy tools and instruments, the nature of the processes of policy formulation, and the manner in which tool choices evolve over time.

28. Hongtao Y, Feiock RC. Policy Tool Interactions and the Adoption of State Renewable Portfolio Standards. Review of Policy Research. 2012;29(2):193-206.

29. Tinbergen J. On the Theory of Economic Policy. Amsterdam, The Netherlands: North-Holland Pub. Co.; 1952.

30. Lejano RP. Frameworks for Policy Analysis: Merging Text and Context. London, UK: Routledge; 2006.

31. Lejano RP, Shankar S. The Contextualist Turn and Schematics of Institutional Fit: Theory and a Case Study from Southern India. Policy Sciences. 2013;46 (1):83-102.

32. Hoffmann MJ. Climate Governance at the Crossroads: Experimenting with a Global Response after Kyoto. Oxford, UK: Oxford University Press; 2011.

33. Vreugdenhil H, Taljaard S, Slinger JH. Pilot Projects and Their Diffusion: A Case Study of Integrated Coastal Management in South Africa. International Journal of Sustainable Development. 2012;15(1-2):148-172.

34. Walker WE, Marchau VAWJ, Swanson D. Addressing Deep Uncertainty Using Adaptive Policies: Introduction to Section 2. Technological Forecasting and Social Change. 2010;77(6):917-923.

35. Swanson D, Barg S, Tyler S, Venema $H$, Tomar S, Bhadwal S, Nair S, Roy D, Drexhage J. Seven Tools for Creating Adaptive Policies. Technological Forecasting and Social Change. 2010;77(6):924-939.

36. McConnell A. Understanding Policy Success: Rethinking Public Policy. Basingstoke, UK: Palgrave Macmillan; 2010.

37. McConnell A. Policy Success, Policy Failure and Grey Areas In-Between. Journal of Public Policy. 2010: 30(3):345-362.

38. Howlett M, Lejano RP. Tales from the Crypt: The Rise and Fall (and Re-Birth?) of Policy Design Studies. Administration \& Society. 2013;45(3):356-380.

39. Knudson WA. The Environment, Energy, and the Tinbergen Rule. Bulletin of Science, Technology \& Society. 2009;29(4):308-312.

40. Doern GB. The Nature of Scientific and Technological Controversy in Federal Policy Formation. Ottawa, Canada: Science Council of Canada; 1981.

41. Doern GB, Phidd RW. Canadian Public Policy: Ideas, Structure, Process. Toronto, Canada: Methuen; 1983.

42. Doern GB. The Nature of Scientific and Technological Controversy in Federal Policy Formation. Ottawa, Canada: Science Council of Canada; 1981.

43. Tupper A, Doern GB. Public Corporations and Public Policy in Canada. In: Tupper A, Doern GB, editors. Public Corporations and Public Policy in Canada. Montreal, Canada: Institute for Research on Public Policy; 1981. pp. 1-50.

44. They first placed only self-regulation, exhortation, subsidies, and regulation on this scale but later added in categories for "taxation" and public enterprise and finally, an entire series of finer "gradiations" within each general category.

45. Doern GB, Wilson VS. Conclusions and Observations. In: Doern GB, Wilson VS, editors. Issues in Canadian Public Policy. Toronto, Canada: Macmillan; 
1974. pp. 337-345.

46. Howlett M. Policy Instruments, Policy Styles, and Policy Implementation: National Approaches to Theories of Instrument Choice. Policy Studies Journal. 1991;19(2):1-21.

47. Woodside K. Policy Instruments and the Study of Public Policy. Canadian Journal of Political Science. 1986;19(4):775-793.

48. Hall PA. Policy Paradigms, Social Learning and the State: The Case of Economic Policy Making in Britain. Comparative Politics. 1993;25(3):275-296.

49. Cashore B, Howlett M. Punctuating Which Equilibrium? Understanding Thermostatic Policy Dynamics in Pacific Northwest Forestry. American Journal of Political Science. 2007;51(3):532-551.

50. Howlett M, Cashore B. The Dependent Variable Problem in the Study of Policy Change: Understanding Policy Change as a Methodological Problem. Journal of Comparative Policy Analysis: Research and Practice. 2009;11(1):33-46.

51. Meijers E, Stead S. Policy Integration: What Does It Mean and How Can It Be Achieved? A Multi-Disciplinary Review. Presented at the Berlin Conference on the Human Dimensions of Global Environmental Change: Greening of Policies-Interlinkages and Policy Integration, Berlin, Germany, 3-4 December 2004.

52. Briassoulis H. Analysis of Policy Integration: Conceptual and Methodological Considerations. In: Briassoulis $\mathrm{H}$, editor. Policy Integration for Complex Environmental Problems: The Example of Mediterranean Desertification. Aldershot, UK: Ashgate; 2005.

53. Meijers E. Policy Integration: A Literature Review. In: Meijers $E$, Stead $D$, Geerlings $H$, editors. Policy Integration in Practice: The Integration of Land Use Planning, Transport and Environmental PolicyMaking in Denmark, England and Germany. Delft, The Netherlands: Delft University Press; 2004. pp. 9-24.

54. Howlett M, Rayner J. Design Principles for Policy Mixes: Cohesion and Coherence in 'New Governance Arrangements'. Policy and Society. 2007;26(4):1-18.

55. Kern F, Howlett M. Implementing Transition Management as Policy Reforms: A Case Study of the Dutch Energy Sector. Policy Sciences. 2009;42(4):391-408.

56. Guy K, Boekholt P, Cunningham P, Hofer R, Nauwelaers C, Rammer C. Designing Policy Mixes: Enhancing Innovation System Performance and R\&D Investment Levels. Final Report. Brussels, Belgium: European Commission; 2008.

57. Keast R, Brown K, Mandell M. Getting the Right Mix: Unpacking Integration Meanings and Strategies. International Public Management Journal. 2007;10 (1):9-33.

58. Howlett M. Policy Design: What, Who, How and Why? In: Halpern $C$, Lascoumes $P$, Le Galès $P$, editors. L'Instrumentation et ses Effets. Paris, France: Presses de Sciences Po; Forthcoming.

59. Howlett M, Muhkerjee I, Wu JJ. The New Policy Design Orientation: From Tools to Toolkits in Policy Instrument Studies. Policy \& Politics; Forthcoming.
60. Howlett M, Rayner J. Convergence and Divergence in 'New Governance' Arrangements: Evidence from European Integrated Natural Resource Strategies. Journal of Public Policy. 2006;26(2):167-189.

61. Rayner J, Howlett M. Conclusion: Governance Arrangements and Policy Capacity for Policy Integration. Policy and Society. 2009;28(2):165-172.

62. Kaufmann D, Gore O. Biotechnology as a Lowlevel-of-coherence Policy Priority: Effectual-targeting and the Need for Learning and Experimentation Capabilities. Technology Analysis \& Strategic Management. 2013;25(7):773-784.

63. Gunningham N, Grabosky P, Sinclair D. Smart Regulation: Designing Environmental Policy. Oxford, UK: Clarendon Press; 1998.

64. Ben-Zadok E. Policy Change Through Policy Design: Florida Concurrency, 1985-2010. Planning Practice and Research. 2013:1-23.

65. Grabosky P. Counterproductive Regulation. International Journal of the Sociology of Law. 1995;23: 347-369.

66. Del Río P, Silvosa AC, Iglesias Gómez G. Policies and Design Elements for the Repowering of Wind Farms: A Qualitative Analysis of Different Options. Energy Policy. 2011;39(4):1897-1908.

67. Boonekamp PGM. Actual Interaction Effects Between Policy Measures for Energy efficiency-A Qualitative Matrix Method and Quantitative Simulation Results for Households. Energy. 2006;31(14):28482873.

68. Schneider $A L$, Ingram $H$. Behavioural Assumptions of Policy Tools. Journal of Politics. 1990;52(2): 511-529.

69. Schneider A, Ingram H. Policy Design: Elements, Premises and Strategies. In: Nagel SS, editor. Policy Theory and Policy Evaluation: Concepts, Knowledge, Causes and Norms. New York, NY, USA: Greenwood; 1990. pp. 77-102.

70. Schneider A, Ingram $H$. Social Construction of Target Populations: Implications for Politics and Policy. American Political Science Review. 1993;87(2):334347.

71. Schneider $A$, Ingram $H$. Social Constructions and Policy Design: Implications for Public Administration. In: Perry J, editor. Research in Public Administration. Greenwich, CT, USA: JAI Press; 1994. pp. 137173.

72. Schneider A, Ingram H. Policy Design for Democracy. Lawrence, KS, USA: University Press of Kansas; 1997.

73. Schneider A, Ingram $H$. Deserving and Entitled: Social Constructions and Public Policy. SUNY Series in Public Policy. Albany, NY, USA: State University of New York; 2005.

74. Hou Y, Brewer G. Substitution and Supplementation Between Co-Functional Policy Instruments: Evidence from State Budget Stabilization Practices. Public Administration Review. 2010;70(6):914-924.

75. Braathen NA. Environmental Agreements Used 
in Combination with Other Policy Instruments. In: Croci $\mathrm{E}$, editor. The Handbook of Environmental Voluntary Agreements. Dodrecht, The Netherlands: Springer; 2005. pp. 335-364.

76. Braathen NA. Instrument Mixes for Environmental Policy: How Many Stones Should Be Used to Kill a Bird? International Review of Environmental and Resource Economics. 2007;1(2):185-235.

77. Gunningham N, Sinclair D. Regulatory Pluralism: Designing Policy Mixes for Environmental Protection. Law and Policy. 1999;21(1):49-76.

78. Eliadis P, Hill MM, Howlett M, editors. Designing Government: From Instruments to Governance. Montreal, Canada: McGill-Queen's University Press; 2005.

79. Howlett M. Governance Modes, Policy Regimes and Operational Plans: A Multi-Level Nested Model of Policy Instrument Choice and Policy Design. Policy Sciences. 2009;42(1):73-89.

80. Arts B, Leroy $P$, van Tatenhove J. Political Modernisation and Policy Arrangements: A Framework for Understanding Environmental Policy Change. Public Organization Review. 2006;6(2):93-106.

81. Arts B, van Tatenhove J, Goverde H. Environmental Policy Arrangements: A New Concept. In: Goverde $\mathrm{H}$, editor. Global and European Polity? Organizations, Policies, Contexts. Aldershot, UK: Ashgate; 2000. pp. 223-237.

82. Kagan RA. Adversarial Legalism: The American Way of Law. Cambridge, MA, USA: Harvard University Press; 2001.

83. Richardson JJ, Gustafsson G, Jordan G. The Concept of Policy Style. In: Richardson JJ, editor. Policy Styles in Western Europe. London, UK: George Allen and Unwin; 1982. pp. 1-16.

84. Freeman GP. National Styles and Policy Sectors: Explaining Structured Variation. Journal of Public Policy. 1985;5(4):467-496.

85. Kiss B, González Manchón C, Neij L. The Role of Policy Instruments in Supporting the Development of Mineral Wool Insulation in Germany, Sweden and the United Kingdom. Journal of Cleaner Production. 2013;48:187-199.

86. Weaver K. Target Compliance: The Final Frontier of Policy Implementation. Washington, DC, USA: Brookings Institution; 2009. Available from: http:// www.brookings.edu/research/papers/2009/09/30-com pliance-weaver (accessed on 10 October 2013).

87. Weaver K. If You Build It, Will They Come? Overcoming Unforeseen Obstacles to Program Effectiveness. The Tansley Lecture, Johnson-Shoyama Graduate School of Public Policy, University of Saskatchewan, Saskatoon, Canada; 16 April 2009.

88. Ingraham $P$. Toward More Systematic Considerations of Policy Design. Policy Studies Journal. 1987; 15(4):611-628.

89. Howlett M, Ramesh M, Perl A. Studying Public Policy: Policy Cycles \& Policy Subsystems. Oxford, UK: Oxford University Press; 2009.

90. Considine M. Enterprising States: The Public Man- agement of Welfare-to-Work. Cambridge, MA, USA: Cambridge University Press; 2001.

91. English LM, Skellern M. Public-Private Partnerships and Public Sector Management Reform; A Comparative Analysis. International Journal of Public Policy. 2005;1(1/2):1-21.

92. Thelen K. How Institutions Evolve: Insights from Comparative Historical Analysis. In: Mahoney J, Rueschemeyer $D$, editors. Comparative Historical Analysis in the Social Sciences. Cambridge, MA, USA: Cambridge University Press; 2003. pp. 208-240.

93. Christensen T, Laegreid P, Wise LR. Transforming Administrative Policy. Public Administration. 2002; 80(1):153-179.

94. Considine M. Thinking Outside the Box? Applying Design Theory to Public Policy. Politics \& Policy. 2012;40(4):704-724.

95. Béland D. Ideas and Institutional Change in Social Security: Conversion, Layering and Policy Drift. Social Science Quarterly. 2007;88(1):20-38.

96. Thelen K. How Institutions Evolve: The Political Economy of Skills in Germany, Britain, the United States and Japan. Cambridge, MA, USA: Cambridge University Press; 2004.

97. Hacker JS. Reform Without Change, Change Without Reform: The Politics of US Health Policy Reform in Comparative Perspective. In: Levin MA, Shapiro MM, editors. Transatlantic Policymaking in an Age of Austerity: Diversity and Drift. Washington, DC, USA: Georgetown University Press; 2004. pp. 13-63.

98. Hacker JS. Review Article: Dismantling the Health Care State? Political Institutions, Public Policies and the Comparative Politics of Health Reform. British Journal of Political Science. 2004;34(4):693-724.

99. van der Heijden J. A short history of studying incremental change. Does Explaining Institutional Change provide any new explanations? Regulation and Governance. 2010;4(2):230-243.

100. Many sustainability strategies, for example, have suffered from layering. For example, efforts at the integration of various resource management regimes that have failed when powerful interests are able to keep favourable goals, instruments and settings, such as unsustainable fishing or timber cutting quotas that support an industry, and limit the impact of new policy initiatives. Drift is a common situation in welfare state mixes whereby, for example, goal shifts from family to individual support (and vice versa) have occurred without necessarily altering the instruments in place to implement the earlier policy goal. Conversion has characterized some major health policy reform efforts, for example Lack of a sustained and focused effort on the part of designers, however, can easily lead to changes in only goals or instruments and hence accomplish changes through drift or conversion, resulting in sub-optimal or disappointing results.

101. Falkenmark M. Towards Integrated Catchment Management: Opening the Paradigm Locks Between 
Hydrology, Ecology and Policy-Making. Water Resources Development. 2004;20(3):275-282.

102. Bode I. Disorganized Welfare Mixes: Voluntary Agencies and New Governance Regimes in Western Europe. Journal of European Social Policy. 2006;16(4): 346-359.

103. Howlett M, Rayner J. Do Ideas Matter? Policy Network Configurations and Resistance to Policy Change in the Canadian Forest Sector. Canadian Public Administration. 1995;38(3):382-410.

104. Orren K, Skowronek S. Regimes and Regime Building in American Government: A Review of Literature on the 1940s. Political Science Quarterly. 1998; 113(4):689-702.

105. Rayner J, Howlett M, Wilson J, Cashore B, Hoberg G. Privileging the Sub-Sector: Critical Sub-Sectors and Sectoral Relationships in Forest Policy-Making. Forest Policy and Economics. 2001;2(3-4):319-332.

106. Hacker JS. Policy Drift: The Hidden Politics of US Welfare State Retrenchment. In: Streeck W, Thelen $\mathrm{K}$, editors. Beyond Continuity: Institutional Change in Advanced Political Economies. Oxford, UK: Oxford University Press; 2005. pp. 40-82.

107. van der Heijden J. Different but Equally Plausible Narratives of Policy Transformation: A Plea for Theoretical Pluralism. International Political Science Review. 2012;34(1):57-73.

108. Kay A. Tense Layering and Synthetic Policy Paradigms: The Politics of Health Insurance in Australia. Australian Journal of Political Science. 2007;42 (4):579-591.

109. Streeck W, Thelen K. Institutional Changes in
Advanced Political Economies. In: Streeck W, Thelen $\mathrm{K}$, editors. Beyond Continuity: Institutional Change in Advanced Political Economies. Oxford, UK: Oxford University Press; 2005.

110. Hickle GT. Moving Beyond the 'Patchwork': A Review of Strategies to Promote Consistency for Extended Producer Responsibility Policy in the US. Journal of Cleaner Production; Forthcoming.

111. Carter P. Policy as Palimpsest. Policy \& Politics. 2012;40(3):423-443.

112. deLeon P. The Contextual Burdens of Policy Design. Policy Studies Journal. 1988;17(2):297-309.

113. Dryzek JS, Ripley B. The Ambitions of Policy Design. Policy Studies Review. 1988;7(4):705-719.

114. Linder SH, Peters BG. Policy Formulation and the Challenge of Conscious Design. Evaluation and Program Planning. 1990;13(3):303-311.

115. Majone G. On the Notion of Political Feasibility. European Journal of Political Research. 1975;3(2): 259-274.

116. May PJ. Policy Maps and Political Feasibility. In: Geva-May I, editor. Thinking like a Policy Analyst: Policy Analysis as a Clinical Profession. London, UK: Palgrave Macmillan; 2005. pp. 127-151.

117. Gilabert P, Lawford-Smith H. Political Feasibility: A Conceptual Exploration. Political Studies. 2012;60(4):809-825.

118. Linder S, Peters BG. The Design of Instruments for Public Policy. In: Nagel SS, editor. Policy Theory and Policy Evaluation: Concepts, Knowledge, Causes, and Norms. New York, NY, USA: Greenwood Press; 1990. pp. 103-119. 